\title{
Changing dynamics of micronutrients in piedmont soil of Bangladesh
}

\section{Md. Mosharaf Hossain Sarker a, *, Md. Jahiruddin b, Abu Zofar Md. Moslehuddin b, Md. Rafiqul Islam ${ }^{b}$}

\author{
a Department of Soil Science, Sylhet Agricultural University, Sylhet, Bangladesh \\ b Department of Soil Science, Bangladesh Agricultural University, Mymensingh, Bangladesh
}

\section{Article Info}

Received : 07.03.2019

Accepted : 23.10.2019

\begin{abstract}
A study was aimed to delineate the micronutrient status, their change directive with time and relationship with other soil variables in piedmont soils of Bangladesh. Northern and Eastern Piedmont Plains (AEZ 22) is one of the 30 agro-ecological zones (AEZs) of the country whose bench mark status of soil micronutrient has been used for comparing with the present status. There is an indication of zinc ( $\mathrm{Zn}$ ) and boron (B) depletion to some extent after a decade of time whereas the very high fertility status of copper $(\mathrm{Cu})$, manganese $(\mathrm{Mn})$ and iron ( $\mathrm{Fe}$ ) prevails as it was in the previous status. In general view, the micronutrient content of surface soil $(0-15 \mathrm{~cm})$ was higher than those of sub-surface soils (15-30 cm). In surface soil clay content showed significant correlation with soil $\mathrm{Zn}$ $\left(\mathrm{r}=0.403^{* *}\right), \mathrm{Cu}\left(\mathrm{r}=0.752^{* *}\right), \mathrm{Fe}\left(\mathrm{r}=0.501^{* *}\right)$ and $\mathrm{Mn}\left(\mathrm{r}=0.340^{* *}\right) . \mathrm{Cu}$ content of soil exhibited positive relationship with all the soil parameters except soil $\mathrm{pH}$ and $\mathrm{P}$ content; there existed highly significant negative correlation of $\mathrm{Cu}$ with soil $\mathrm{pH}\left(\mathrm{r}=-0.578^{* *}\right)$ and $\mathrm{P}\left(\mathrm{r}=-0.420^{* *}\right)$. The availability of Fe in soil was strongly related with soil clay content $\left(r=0.501^{* *}\right)$, soil $\mathrm{pH}$ $\left(\mathrm{r}=-0.686^{* *}\right)$ and organic matter content $\left(\mathrm{r}=0.527^{* *}\right)$. In surface soil, Fe content influenced significantly with the content of $\mathrm{Zn}, \mathrm{Cu}$ and $\mathrm{Mn}$. Accordingly in sub-surface soil, positive significant interaction of $\mathrm{Zn}-\mathrm{Fe}, \mathrm{Cu}-\mathrm{Fe}, \mathrm{Cu}-\mathrm{Mn}$ and $\mathrm{Fe}-\mathrm{Mn}$ was observed. The message revealed from this study concerning nutrient depletion, and interactions among different soil parameters and nutrient elements will pave the way for efficient use of soil resources in a sustainable way.
\end{abstract}

Keywords: Change directive, interaction, micronutrient, piedmont soil, status.

(C) 2020 Federation of Eurasian Soil Science Societies. All rights reserved

\section{Introduction}

Once upon Bangladesh was a land of fertile soils; now it is in the eve of loosing its glory. Over the last 2-3 decades, enormous pressure has been exerted on its soil resources to produce more food for the ever increasing population of the country. Soil degradation has far reaching consequences particularly in relation to crop production and environmental stability (Lal and Stewart, 1992). Declining productivity in Bangladesh due to the decrease of soil fertility has been cited by many authors (Islam, 1990; Saunders, 1990, 1991; Ali, 1991; Saheed, 1991, 1994). Intensification of agricultural land use has increased remarkably, along with increasing use of modern crop varieties, which in turn has resulted in deterioration of soil fertility with emergence of new nutrient deficiencies. In 1983-84, the cropping intensity of the country was $171 \%$ whereas it was 194\% in 2015-16 (BBS, 2017). Accordingly, coverage of HYVs and hybrid varieties of only rice increased from 2631 thousand ha in 1983-84 to 9685 thousand ha in 2015-16 (BBS, 2017; BBS, 2018). As a consequence, soil fertility is declining day by day (Islam, 2008; SRDI, 2010a,b). Hence, chronologically N, P, K, S, Zn and B deficiency have arisen in this country's soils (Jahiruddin and Satter, 2010). On the other hand, cropping systems have undergone some drastic changes since 1973 due to the adoption of high

\footnotetext{
${ }^{*}$ Corresponding author.

Department of Soil Science, Sylhet Agricultural University, Sylhet-3100, Bangladesh

Tel.: +8801716165746

e-ISSN: 2147-4249
}

E-mail address: mosharaf_srdi@yahoo.com DOI: $10.18393 /$ ejss.642221 
yielding varieties along with increased use of irrigation and fertilizer (Huq et al., 1990). Natural disasters (e.g. floods, cyclones, drought etc.), human interference (Farakka barrage etc.), over intensification due to population pressure, deforestation, low supply of recyclable organic matter and other types of agricultural mismanagement might exert adverse long-term effects on the soils of Bangladesh. Among the agro-ecological zones (AEZs) of the country, Northern and Eastern Piedmont Plains (AEZ 22) is an important one considering land coverage of 4,03,758 ha as well as crop cultivation (BARC, 2012).

Zinc deficiencies in rice were observed in early 1980s in Bangladesh. Among the crops maize and rice have been found to be more sensetive to zinc deficiency (Akhter et al., 1990; Islam et al., 1997; Alam et al., 2000). Boron deficiency of some crops is reported in early 1990's. Sporadic information of Cu and Mn deficiencies in crops has been reported (Bhuiyan et al., 1998; Khanam et al., 2000; Ferdoush et al., 2003). Among the micronutrients $\mathrm{Fe}$ and $\mathrm{Cl}$ deficiencies are not yet reported in Bangladesh. The Zn deficiency in rice was first identified at Bangladesh Rice Research Institute (BRRI) and concurrently at Bangladesh Agricultural University (BAU) (Bhuiya et al., 1981; Jahiruddin et al., 1981). Thereafter, the status of Zn in soils and crop plants, and areas prone to Zn deficiency in rice were identified through the "FAO-BARC Coordinated Programme on Zn and S Deficiencies of Bangladesh Soils", with the participation of several institutes viz. Bangladesh Rice Research Institute (BRRI), Bangladesh Agricultural Research Institute (BARI), Bangladesh Institute of Nuclear Agriculture (BINA) and Bangladesh Agricultural University (BAU) (Islam, 1984). Considering the above aspects, deficient micronutrient along with it deficient zones in the country should be identified. In addition to that it is essential to know about the depleting trend of those nutrients and interacting factors related to the issue. Hence, the present study was undertaken to avail the information related to the change in soil micronutrients, their depleting mode and the influencing factors act on them in the aforesaid AEZ.

\section{Material and Methods}

\section{Previous soil data collection}

Soil Resource Development Institute, a leading soil research institute in Bangladesh generated the previous soil fertility status of AEZ 22 through respective Upazila Nirdeshika (Adorsho Sadar and Burichong upazila of Cumilla district. Previous soil analytical data were collected from those Upazila Nirdeshika.

\section{Collection of soil samples}

Soil sampling was done from the representative sites of the study area to delineate the the present fertility status. The sampling sites were selected based on the existing cropping pattern, land type and soil series. The corresponding previous sampling spots, cited in the respective Upazila Nirdeshikas were also in consideration. The highest efforts were given for selecting the same/closer spots to the previous sampling spots maintaining the above mentioned criteria. GPS reading was recorded for each site. Fifty sampling sites were selected, and from each site two samples were collected at two soil depths $(0-15 \mathrm{~cm}$ and $15-30 \mathrm{~cm})$. The collected soil samples were spread on brown paper in the laboratory for air-drying. After removing the plant roots and other debris the air-dried soil was ground and passed through a 2-mm sieve. The processed samples were kept in polyethylene bags.

\section{Chemical analysis of processed soil samples}

Subsequently, the soil samples have been analyzed for basic soil properties ( $\mathrm{pH}$, organic matter and texture), macronutrient $(\mathrm{N}, \mathrm{P}, \mathrm{K}, \mathrm{S}, \mathrm{Ca}$ and $\mathrm{Mg}$ ) and micronutrient $(\mathrm{Cu}, \mathrm{Fe}, \mathrm{Mn}, \mathrm{Zn}$ and $\mathrm{B})$ status following standard methodology as described in Table 1.

\section{Processing and statistical analysis of soil analytical data}

The analytical results of soil samples have been categorized into very low, low, medium, high and very high status. Similarly, the status of basic soil parameters also used in such categorization (BARC, 2012). Relationship between each nutrient and other soil characteristics were examined by correlation analysis (Gomez and Gomez, 1984). A comparative feature was developed using the analytical data derived from collected soil samples and the previous available data from respective Upazila Nirdeshika (SRDI, 1999, 2000, 2006). The analytical results derived from collected soil samples and Upazila Nirdeshika is denoted in this manuscript as present and previous status, respectively. Standard statistical tools were used in comparing the data by using Microsoft Excel (Gomez and Gomez, 1984). 
Table 1. Methods for analysis of soil properties

\begin{tabular}{|c|c|}
\hline Soil properties & Analytical methods \\
\hline $\mathrm{pH}$ & $\begin{array}{l}\text { Soil pH was determined by glass-electrode } \mathrm{pH} \text { meter maintaining 1:2.5 soil-water ratio } \\
\text { (McLean, 1982) }\end{array}$ \\
\hline Texture & $\begin{array}{l}\text { Mechanical analysis of soil was done by Hydrometer method (Gee and Bauder, 1986) and the } \\
\text { textural class was determined by fitting the values for \%sand, \%silt and \%clay to the Marshall's } \\
\text { triangular co-ordinate following USDA system }\end{array}$ \\
\hline Organic carbon & $\begin{array}{l}\text { Following wet oxidation method (Nelson and Sommers, 1996), the soil organic matter was } \\
\text { oxidized by } 1 \mathrm{~N} \text { potassium dichromate and the amount of organic carbon in the aliquot was } \\
\text { determined by titration against } 0.5 \mathrm{~N} \text { ferrous sulphate hepta-hydrate solution. The amount of } \\
\text { organic matter was calculated by multiplying the percent organic carbon with the van } \\
\text { Bemmelen factor } 1.73 \text { (Piper, 1950) }\end{array}$ \\
\hline Total N & $\begin{array}{l}\text { Total } \mathrm{N} \text { content of soil was determined by micro-Kjeldahl method (Bremner and Mulvaney, } \\
1982) \text {. Soil sample was digested with conc. } \mathrm{H}_{2} \mathrm{SO}_{4} \text { in presence of catalyst mixture } \\
\left(\mathrm{K}_{2} \mathrm{SO}_{4}: \mathrm{CuSO}_{4} \cdot 5 \mathrm{H}_{2} \mathrm{O}: \mathrm{Se}=10: 1: 0.1\right) \text {. Nitrogen in the digest was estimated by distilling the digest } \\
\text { with } 10 \mathrm{~N} \mathrm{NaOH} \text { followed by titration of the distillate trapped into } \mathrm{H}_{3} \mathrm{BO}_{3} \text { indicator solution with } \\
0.01 \mathrm{~N} \mathrm{H}_{2} \mathrm{SO}_{4}\end{array}$ \\
\hline Available P & $\begin{array}{l}\text { Soils having pH smaller than } 7.0 \text { were extracted with ammonium fluoride extracting solution } \\
(\text { Bray and Kurtz's, 1945) and soils having pH greater than } 7.0 \text { were extracted with } 0.5 \mathrm{M} \\
\mathrm{NaHCO}_{3} \text { solution (Olsen and Sommers, 1982). The P in the extract was then determined by } \\
\text { developing blue colour with } \mathrm{SnCl}_{2} \text { reduction of phosphomolybdate complex and measuring the } \\
\text { colour by spectrophotometer at } 660 \mathrm{~nm} \text { wave length }\end{array}$ \\
\hline $\begin{array}{l}\text { Exchangeable } \\
\mathrm{Ca}, \mathrm{Mg}, \mathrm{K}\end{array}$ & $\begin{array}{l}\text { These elements were extracted from soil by } 1 \mathrm{M} \mathrm{CH}_{3} \mathrm{COONH}_{4} \text { with a } 1: 10 \text { soil-extractant ratio } \\
\text { and the extractable amount was determined by flame AAS for } \mathrm{Ca} \& \mathrm{Mg} \text { and by flame } \\
\text { photometer for } \mathrm{K} \text { (Knudsen et al., 1982) }\end{array}$ \\
\hline Available S & $\begin{array}{l}\text { Extraction was done with } \mathrm{CaCl}_{2}(0.15 \%) \text { solution as described by Tabatabai (1996). The S } \\
\text { content in the extract was determined turbidimetrically using a spectrophotometer at } 420 \mathrm{~nm} \\
\text { wave length (Fox et al., 1964; Jones et al., 1972) }\end{array}$ \\
\hline $\begin{array}{l}\text { Available } \\
\mathrm{Zn}, \mathrm{Cu}, \mathrm{Mn}, \mathrm{Fe}\end{array}$ & $\begin{array}{l}\text { These micronutrients were extracted by } 0.05 \mathrm{M} \text { DTPA solution (pH 7.3) maintaining 1:2 soil- } \\
\text { extractant ratio. The extracted level was measured by flame AAS (Lindsay and Norvell, 1978) }\end{array}$ \\
\hline Available B & $\begin{array}{l}\text { Soil B was extracted by hot water-0.02 } \mathrm{M} \mathrm{CaCl}_{2} \text { solution }(1: 2) . \text { The extractable B was determined } \\
\text { by spectrophotometer following azomethine-H method (Keren, 1996) }\end{array}$ \\
\hline
\end{tabular}

\section{Results}

\section{Present status of soil micronutrient and its deviation from respective previous one}

Different data as mean, maximum, minimum and standard deviation for each micronutrient derived from chemical analysis of soil is summerized in Table 2. Previous status of the micronutrients is also presented in the same table for comparing both statuses. Comparison was done between present statuses of each micronutrient with their corresponding previous one, as recorded in Upazila Nirdeshika. The soil samples incorporated in those Upazila Nirdeshika were collected from field during 1996-2003. Hence, almost a decade of time gap between present and previous soil analytical results. Comparison between present and previous status of different micronutrients are graphically shown in Figures 1-5.

Table 2.Summary of zinc, boron, copper, iron and manganese levels $\left(\mathrm{mg} \mathrm{kg}^{-1}\right)$ of soils at two depths $(\mathrm{n}=50)$

a) Present status

\begin{tabular}{|c|c|c|c|c|c|c|c|c|}
\hline \multirow{2}{*}{ Micronutrients } & \multicolumn{4}{|c|}{$0-15 \mathrm{~cm}$ soil depth } & \multicolumn{4}{|c|}{$15-30 \mathrm{~cm}$ soil depth } \\
\hline & $\begin{array}{c}\text { Min. } \\
\left(\mu \mathrm{g} \mathrm{g}^{-1}\right)\end{array}$ & $\begin{array}{c}\text { Max. } \\
\left(\mu \mathrm{g} \mathrm{g}^{-1}\right)\end{array}$ & $\begin{array}{c}\text { Mean } \\
\left(\mu \mathrm{g} \mathrm{g}^{-1}\right)\end{array}$ & SD & $\begin{array}{c}\text { Min. } \\
\left(\mu \mathrm{g} \mathrm{g}^{-1}\right)\end{array}$ & $\begin{array}{c}\text { Max. } \\
\left(\mu \mathrm{g} \mathrm{g}^{-1}\right)\end{array}$ & $\begin{array}{c}\text { Mean } \\
\left(\mu \mathrm{g} \mathrm{g}^{-1}\right)\end{array}$ & SD \\
\hline $\mathrm{Zn}$ & 0.54 & 3.28 & 1.681 & 0.789 & 0.45 & 4.49 & 1.21 & 0.77 \\
\hline $\mathrm{B}$ & 0.10 & 0.50 & 0.27 & 0.10 & 0.08 & 0.33 & 0.18 & 0.08 \\
\hline $\mathrm{Cu}$ & 0.98 & 7.58 & 3.49 & 1.67 & 0.64 & 8.67 & 2.83 & 1.75 \\
\hline $\mathrm{Fe}$ & 43.0 & 397 & 217 & 79 & 19.0 & 200 & 91.0 & 48.47 \\
\hline $\mathrm{Mn}$ & 17.0 & 91.0 & 45.1 & 20.7 & 9.6 & 67.4 & 28.8 & 14.81 \\
\hline \multicolumn{9}{|l|}{ b) Previous status } \\
\hline \multirow{2}{*}{ Micronutrients } & \multicolumn{8}{|c|}{$0-15 \mathrm{~cm}$ soil depth } \\
\hline & \multicolumn{2}{|c|}{$\operatorname{Min} .\left(\mu g^{-1}\right)$} & \multicolumn{2}{|c|}{ Max. $\left(\mu g^{-1}\right)$} & \multicolumn{2}{|c|}{ Mean $\left(\mu \mathrm{g} \mathrm{g}^{-1}\right)$} & \multicolumn{2}{|l|}{ SD } \\
\hline $\mathrm{Zn}$ & \multicolumn{2}{|c|}{0.30} & \multicolumn{2}{|c|}{3.90} & \multicolumn{2}{|c|}{2.62} & \multicolumn{2}{|c|}{0.856} \\
\hline B & \multicolumn{2}{|c|}{0.11} & \multicolumn{2}{|c|}{0.54} & \multicolumn{2}{|c|}{0.33} & \multicolumn{2}{|c|}{0.130} \\
\hline $\mathrm{Cu}$ & \multicolumn{2}{|c|}{0.50} & \multicolumn{2}{|c|}{9.40} & \multicolumn{2}{|c|}{4.12} & \multicolumn{2}{|l|}{1.810} \\
\hline $\mathrm{Fe}$ & \multicolumn{2}{|c|}{12.00} & \multicolumn{2}{|c|}{475} & \multicolumn{2}{|c|}{195} & \multicolumn{2}{|l|}{114} \\
\hline $\mathrm{Mn}$ & \multicolumn{2}{|c|}{4.00} & \multicolumn{2}{|c|}{171} & \multicolumn{2}{|c|}{44.60} & \multicolumn{2}{|c|}{36.60} \\
\hline
\end{tabular}




\section{Status of plant available zinc}

After almost a decade of time, a clear depletion was observed in soil Zn status of the study area (Figure 1). The available $\mathrm{Zn}$ ranged in surface soil $\left(0-15 \mathrm{~cm}\right.$ depth) from 0.30 to 3.90 and 0.54 to $3.28 \mu \mathrm{g} \mathrm{g}^{-1}$ with the averages of 2.62 and $1.68 \mathrm{mg} \mathrm{kg}^{-1}$ in previous and present investigations, respectively. On the other hand, present sub-surface soil had available $\mathrm{Zn}$ status varied from 0.45 to $4.49 \mu \mathrm{g} \mathrm{g}^{-1}$. Previously, surface soil $\mathrm{Zn}$ status was $2 \%$ very low, $2 \%$ low, $10 \%$ medium, $8 \%$ optimum, $14 \%$ high and $64 \%$ very high, and in present situation it is $16 \%$ low, $30 \%$ medium, $24 \%$ optimum, $6 \%$ high and $24 \%$ very high.

\section{Status of plant available boron}

Available B in surface soil varied from 0.11 to 0.54 and 0.10 to $0.50 \mu \mathrm{g} \mathrm{g}^{-1}$ having the averages 0.33 and $0.27 \mu \mathrm{g} \mathrm{g}^{-1}$ in previous and present status, respectively. Again, it ranged from 0.08 to $0.33 \mu \mathrm{g} \mathrm{g}^{-1}$ with an average value $0.18 \mu \mathrm{g} \mathrm{g}^{-1}$ in present sub-surface soil. Among the soil samples studied, $20 \%$ hold very low, $33 \%$ low, $37 \%$ medium and $10 \%$ optimum B in previous status, while it was $10 \%$ very low, $40 \%$ low, $46 \%$ medium and $4 \%$ optimum in present data (Figure 2 ).

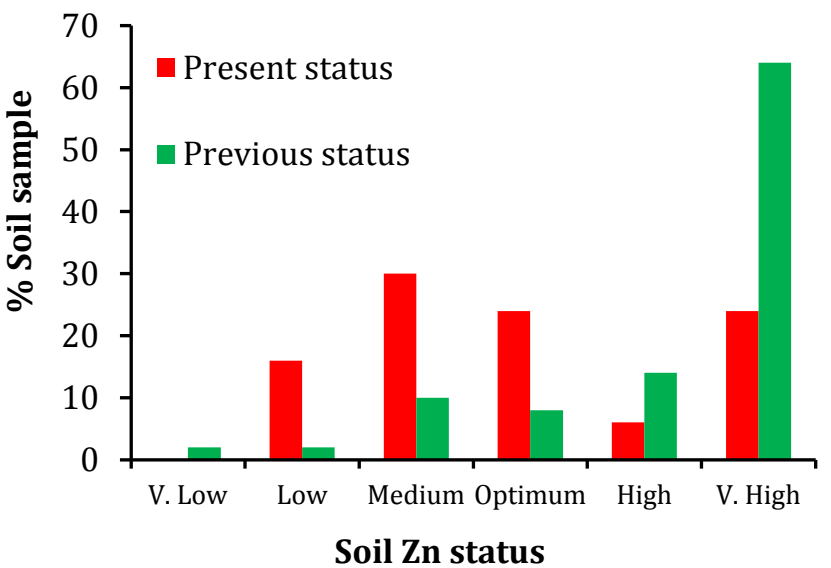

Figure 1. Changing trend of soil available Zn status over time in AEZ 22

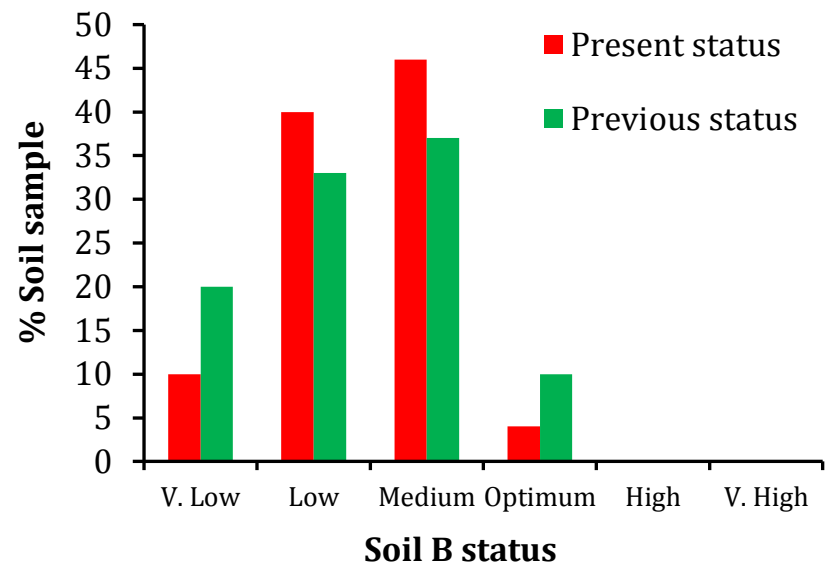

Figure 2. Changing trend of soil available B status over time in AEZ 22

\section{Status of plant available copper}

The available $\mathrm{Cu}$ status in surface soil ranged from 0.50 to 9.40 and 0.98 to $7.58 \mu \mathrm{g} \mathrm{g}^{-1}$ having the averages 4.12 and $3.49 \mu \mathrm{g} \mathrm{g}^{-1}$ in previous and present fertility, respectively. On the other hand, it was from 0.64 to 8.67 $\mu \mathrm{g} \mathrm{g}^{-1}$ in present sub-surface soil where the average value was $2.83 \mu \mathrm{g} \mathrm{g}^{-1}$. In both previous and present surface soil, very high status of available $\mathrm{Cu}$ was reported (Figure 3).

\section{Status of plant available iron}

The soil status of available Fe was very high in both previous and present fertility (Figure 4). It varied from 12.0 to 475 and 43 to $397 \mu \mathrm{g} \mathrm{g}^{-1}$ having the average values of 195 and $217 \mu \mathrm{g} \mathrm{g}^{-1}$ in previous and present data, respectively. Again in present sub-surface soil, it was from 19 to $200 \mu \mathrm{g} \mathrm{g}^{-1}$ with an average of $91 \mu \mathrm{g} \mathrm{g}^{-1}$.

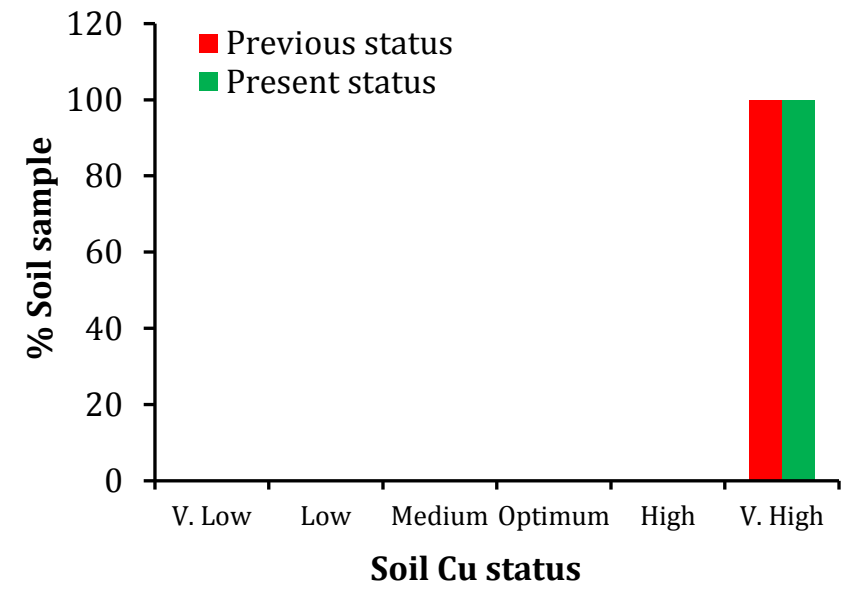

Figure 3. Changing trend of soil available $\mathrm{Cu}$ status over time in AEZ 22

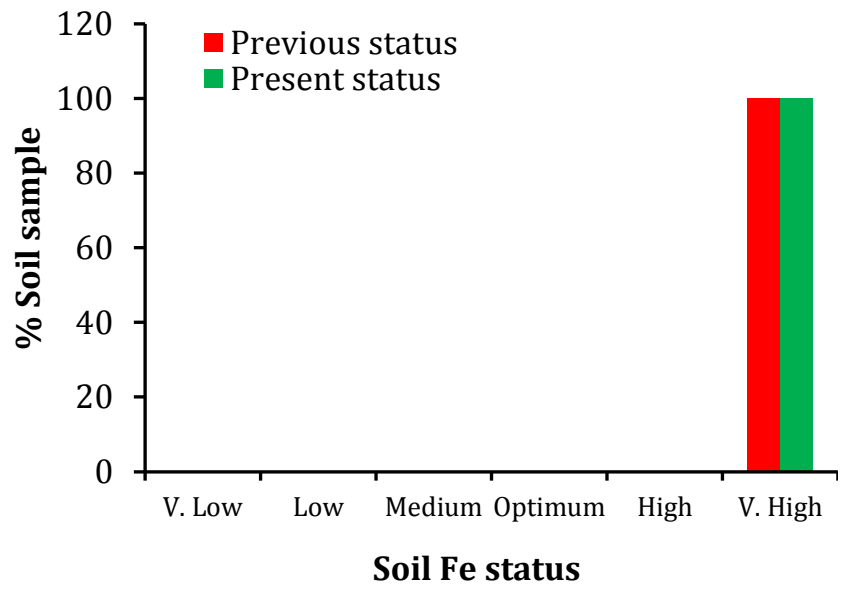

Figure 4. Changing trend of soil available Fe status over time in AEZ 22 


\section{Status of plant available manganese}

In all cases, the soil status of available Mn categorized as very high in both previous and present status, and it ranged from 4.0 to 171 and 17.0 to $91.0 \mu \mathrm{g} \mathrm{g}{ }^{-1}$ with an average of 44.6 and $45.1 \mu \mathrm{g} \mathrm{g}^{-1}$ in previous and present data, respectively (Figure 5). Again, the range was 9.6 to $67.4 \mu \mathrm{g} \mathrm{g}^{-1}$ in present sub-surface soil where the average content was $28.8 \mu \mathrm{g} \mathrm{g}^{-1}$.

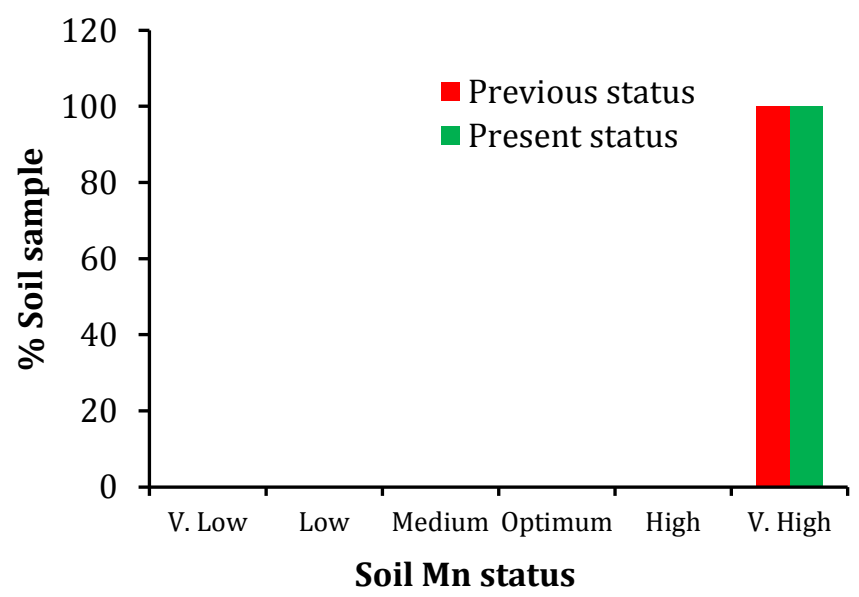

Figure 5. Changing trend of soil available Mn status over time in AEZ 22

\section{Relationship of micronutrients status with other soil variables}

Correlation statistics was performed to examine the relationship of micronutrients with other soil variables and to see the interrelationship among the micronutrients. This statistics was done separately for surface and sub-surface soils (Tables 3 and 4). The number of soil samples i.e. observations for both cases were 50.

Table 3. Correlation matrix of soil variables (soil collection at 0-15 cm depth)

a) Relationship of micronutrients with other soil variables $(\mathrm{n}=50)$

\begin{tabular}{lccccccccc}
\hline Micronutrients & Clay & $\mathrm{pH}$ & $\mathrm{OM}$ & $\mathrm{N}$ & $\mathrm{P}$ & $\mathrm{K}$ & $\mathrm{Ca}$ & $\mathrm{Mg}$ & $\mathrm{S}$ \\
\hline $\mathrm{Zn}$ & $0.403^{* *}$ & $-0.192^{\mathrm{ns}}$ & $0.048^{\mathrm{ns}}$ & $-0.045^{\mathrm{ns}}$ & $0.368^{* *}$ & $0.366^{* *}$ & $0.077^{\mathrm{ns}}$ & $-0.015^{\mathrm{ns}}$ & $0.177^{\mathrm{ns}}$ \\
$\mathrm{B}$ & $-0.202^{\mathrm{ns}}$ & $-0.008^{\mathrm{ns}}$ & $-0.191^{\mathrm{ns}}$ & $-0.129^{\mathrm{ns}}$ & $0.205^{\mathrm{ns}}$ & $-0.052^{\mathrm{ns}}$ & $-0.181^{\mathrm{ns}}$ & $-0.137^{\mathrm{ns}}$ & $0.052^{\text {ns }}$ \\
$\mathrm{Cu}$ & $0.752^{* *}$ & $-0.578^{* *}$ & $0.565^{* *}$ & $0.509^{* *}$ & $-0.420^{* *}$ & $0.650^{* *}$ & $0.770^{* *}$ & $0.629^{* *}$ & $0.497^{* *}$ \\
$\mathrm{Fe}$ & $0.501^{* *}$ & $-0.686^{* *}$ & $0.527^{* *}$ & $0.480^{* *}$ & $-0.082^{\text {ns }}$ & $0.520^{* *}$ & $0.435^{* *}$ & $0.243^{\text {ns }}$ & $0.540^{* *}$ \\
$\mathrm{Mn}$ & $0.340^{*}$ & $-0.255^{\mathrm{ns}}$ & $0.299^{*}$ & $0.420^{* *}$ & $-0.290^{*}$ & $0.430^{* *}$ & $0.309^{*}$ & $0.232^{\text {ns }}$ & $0.397^{* *}$ \\
\hline
\end{tabular}

b) Interrelationship among micronutrients in soils $(\mathrm{n}=50)$

\begin{tabular}{lcccc}
\hline Micronutrients & $\mathrm{Zn}$ & $\mathrm{B}$ & $\mathrm{Cu}$ & $\mathrm{Fe}$ \\
\hline $\mathrm{Zn}$ & - & & & \\
$\mathrm{B}$ & $-0.004^{\mathrm{ns}}$ & - & - & - \\
$\mathrm{Cu}$ & $0.178^{\mathrm{ns}}$ & $-0.198^{\mathrm{ns}}$ & $0.563^{* *}$ & $0.154^{\mathrm{ns}}$ \\
$\mathrm{Fe}$ & $0.293^{*}$ & $0.025^{\mathrm{ns}}$ & $-359^{* *}$ \\
$\mathrm{Mn}$ & $0.083^{\mathrm{ns}}$ & $-0.055^{\mathrm{ns}}$ & $0.1 \%$ \\
\hline
\end{tabular}

${ }^{*}=$ Significant at $5 \%$ level, ${ }^{* *}=$ Significant at $1 \%$ level, $\mathrm{ns}=$ Not significant

Table 4. Correlation matrix of soil variables (soil collection at $15-30 \mathrm{~cm}$ depth)

a) Relationship of micronutrients with other soil variables $(n=50)$

\begin{tabular}{llllllllll}
\hline Micronutrients & \multicolumn{1}{c}{ Clay } & \multicolumn{1}{c}{$\mathrm{pH}$} & $\mathrm{OM}$ & $\mathrm{N}$ & $\mathrm{P}$ & $\mathrm{K}$ & $\mathrm{Ca}$ & $\mathrm{Mg}$ & $\mathrm{S}$ \\
\hline $\mathrm{Zn}$ & $0.080^{\mathrm{ns}}$ & $-0.437^{* *}$ & $0.167^{\mathrm{ns}}$ & $0.036^{\mathrm{ns}}$ & $0.719^{* *}$ & $0.291^{*}$ & $-0.156^{\mathrm{ns}}$ & $-0.182^{\mathrm{ns}}$ & $0.113^{\mathrm{ns}}$ \\
$\mathrm{B}$ & $-0.134^{\mathrm{ns}}$ & $0.178^{\mathrm{ns}}$ & $-0.129^{\mathrm{ns}}$ & $-0.255^{*}$ & $0.119^{\mathrm{ns}}$ & $-0.051^{\mathrm{ns}}$ & $-0.045^{\mathrm{ns}}$ & $-0.035^{\mathrm{ns}}$ & $0.187^{\mathrm{ns}}$ \\
$\mathrm{Cu}$ & $0.713^{* *}$ & $-0.305^{*}$ & $0.654^{* *}$ & $0.557^{* *}$ & $-0.219^{\mathrm{ns}}$ & $0.601^{* *}$ & $0.545^{* *}$ & $0.399^{* *}$ & $0.259^{*}$ \\
$\mathrm{Fe}$ & $0.344^{*}$ & $-0.666^{* *}$ & $0.593^{* *}$ & $0.368^{* *}$ & $0.237^{\mathrm{ns}}$ & $0.300^{*}$ & $0.123^{\mathrm{ns}}$ & $-0.063^{\mathrm{ns}}$ & $0.374^{* *}$ \\
$\mathrm{Mn}$ & $0.388^{* *}$ & $-0.254^{\mathrm{ns}}$ & $0.247^{\mathrm{ns}}$ & $0.163^{\mathrm{ns}}$ & $-0.153^{\mathrm{ns}}$ & $0.345^{* *}$ & $0.267^{*}$ & $0.287^{*}$ & $0.327^{*}$ \\
\hline
\end{tabular}

b) Interrelationship among micronutrients in soils $(n=50)$

\begin{tabular}{lcccc}
\hline Micronutrients & $\mathrm{Zn}$ & $\mathrm{B}$ & $\mathrm{Cu}$ & $\mathrm{Fe}$ \\
\hline $\mathrm{Zn}$ & - & & & \\
$\mathrm{B}$ & $0.047^{\mathrm{ns}}$ & - & - & - \\
$\mathrm{Cu}$ & $0.221^{\mathrm{ns}}$ & $-0.200^{\mathrm{ns}}$ & $0.573^{* *}$ & $0.456^{* *}$ \\
$\mathrm{Fe}$ & $0.415^{* *}$ & $0.029^{\mathrm{ns}}$ & $0.479^{* *}$ & $0.060^{\mathrm{ns}}$ \\
$\mathrm{Mn}$ & $0.173^{\mathrm{ns}}$ & $0.00 \mathrm{n}$ & \\
\hline
\end{tabular}

$*=$ Significant at 5\% level, ${ }^{* *}=$ Significant at 1\% level, ns = Not significant 


\section{Characteristics of surface soil $(0-15 \mathrm{~cm}$ soil depth)}

Clay content of soil showed significant correlation with soil $\mathrm{Zn}\left(\mathrm{r}=0.403^{* *}\right), \mathrm{Cu}\left(\mathrm{r}=0.752^{* *}\right), \mathrm{Fe}\left(\mathrm{r}=0.501^{* *}\right)$ and $\mathrm{Mn}\left(\mathrm{r}=0.340^{* *}\right)$ (Table 3$)$. The $\mathrm{Zn}$ content showed significant relationship with available $\mathrm{P}\left(\mathrm{r}=0.368^{* *}\right)$ and exchangeable $\mathrm{K}\left(\mathrm{r}=0.366^{* *}\right)$ content of soil. Among the micronutrients under study, the soil B content exhibited positive but non-significant relationship with soil $\mathrm{P}(\mathrm{r}=0.205)$ and weak relation with $\mathrm{S}$ content $(\mathrm{r}=0.052)$; while it showed negative relation with all other soil characteristics under study. The $\mathrm{Cu}$ availability in soil was influenced by many soil variables. $\mathrm{Cu}$ content of soil exhibited positive relationship with all the soil parameters except soil $\mathrm{pH}$ and $\mathrm{P}$ content; there existed highly significant negative correlation of $\mathrm{Cu}$ with soil $\mathrm{pH}\left(\mathrm{r}=-0.578^{* *}\right)$ and $\mathrm{P}$ content $\left(\mathrm{r}=-0.420^{* *}\right)$. The availability of $\mathrm{Fe}$ in soil was highly related with soil clay content $\left(\mathrm{r}=0.501^{* *}\right)$, soil $\mathrm{pH}\left(\mathrm{r}=-0.686^{* *}\right)$, organic matter $\left(\mathrm{r}=0.527^{* *}\right)$, total $\mathrm{N}\left(\mathrm{r}=0.480^{* *}\right), \mathrm{K}$ $(\mathrm{r}=0.520), \mathrm{Ca}\left(\mathrm{r}=0.435^{* *}\right), \mathrm{Mg}(\mathrm{r}=0.243)$ and $\mathrm{S}$ content $\left(\mathrm{r}=0.540^{* *}\right)$. Accordingly, the soil Mn level showed significant relationship with clay content, organic matter $\left(\mathrm{r}=0.299^{*}\right)$, total $\mathrm{N}\left(\mathrm{r}=0.420^{* *}\right), \mathrm{P}\left(\mathrm{r}=0.290^{*}\right), \mathrm{K}$ $\left(\mathrm{r}=0.430^{* *}\right)$, Ca $\left(\mathrm{r}=0.309^{* *}\right)$ and $\mathrm{S}$ content $\left(\mathrm{r}=0.397^{* *}\right)$. Incase of interrelationship among soil micronutrients, soil $\mathrm{Cu}$ content showed non-significant positive interaction with soil $\mathrm{Zn}$ content ( $\mathrm{r}=0.178$ ) and negative interaction with soil B content $(\mathrm{r}=-0.198)$. Soil Fe content influenced signicantly by $\mathrm{Zn}\left(\mathrm{r}=0.293^{*}\right), \mathrm{Cu}$ $\left(\mathrm{r}=0.563^{* *}\right)$ and Mn content $\left(\mathrm{r}=0.359^{* *}\right)$.

\section{Characteristics of sub-suface soil (15-30 cm soil depth)}

Like surface soils, availability of $\mathrm{Zn}, \mathrm{Cu}, \mathrm{Fe}$ and $\mathrm{Mn}$ in sub-surface soils was markedly influenced by many other soil variables (Table 4). Other than soil B, all the micronutrient contents were negatively correlated with soil $\mathrm{pH}$ indicating that micronutrient availability decreases as soil $\mathrm{pH}$ increases and vice-versa. This point is very important for soil fertility concern. $\mathrm{Cu}$, Fe and $\mathrm{Mn}$ content were significantly correlated with clay content $\left(\mathrm{r}=0.713^{*}, \mathrm{r}=0.344^{* *}\right.$ and $\mathrm{r}=0.388^{* *}$, respectively). Significant positive relationship of soil organic matter with soil $\mathrm{Cu}\left(\mathrm{r}=0.654^{* *}\right)$ and $\mathrm{Fe}\left(\mathrm{r}=0.593^{* *}\right)$ was observed. The $\mathrm{Cu}$ and $\mathrm{Fe}$ content in soil was positively correlated with soil $\mathrm{N}$ content, $\mathrm{r}$ values being $0.557^{* *}$ and $0.368^{* *}$, respectively, while $\mathrm{B}$ content was negatively related $\left(\mathrm{r}=-0.255^{*}\right)$ with $\mathrm{N}$ content. Soil $\mathrm{P}$ content was associated only with $\mathrm{Zn}$ content $\left(\mathrm{r}=0.719^{*}\right)$. K content significantly correlated with soil $\mathrm{Zn}\left(\mathrm{r}=0.291^{*}\right), \mathrm{Cu}\left(\mathrm{r}=0.601^{* *}\right)$, Fe $\left(\mathrm{r}=0.300^{*}\right)$ and $\mathrm{Mn}$ $\left(\mathrm{r}=0.345^{* *}\right)$ content. The contents of other basic cations viz. Ca and Mg were found positively associated with $\mathrm{Cu}$ and $\mathrm{Mn}$ contents in soil. Soil S content was also positively affected micronutrient availability in soil. There was significant positive interaction of $\mathrm{Zn}-\mathrm{Fe}\left(\mathrm{r}=0.415^{* *}\right), \mathrm{Cu}-\mathrm{Fe}\left(\mathrm{r}=0.573^{* *}\right), \mathrm{Cu}-\mathrm{Mn}\left(\mathrm{r}=0.479^{* *}\right)$ and $\mathrm{Fe}-\mathrm{Mn}$ $\left(\mathrm{r}=0.456^{* *}\right)$ in soil. The other interactions were not significant.

\section{Discussion}

Comparing both present and previous statuses of $\mathrm{Zn}$, it is observed that lower statuses have improved to some extent over time. According to BARC (2012), low to medium and very low to low status of $\mathrm{Zn}$ and B, respectively, prevailed in soils of AEZ 22. An indication of depleting trend was observed in soil zinc and boron status of the study area after almost a decade of time. For such negative changes, high cropping intensity along with cultivation of modern varieties of crop might be contributed a lot. Depleting trend of soil $\mathrm{Zn}$ and B in some areas of Bangladesh was reported by some researchers (Siddique et al., 2014). The most B deficient areas are Dinajpur, Rangpur, Bogra, Sirajganj, Cumilla and Sylhet (SRDI, 2010b). Considering available $\mathrm{Cu}, \mathrm{Mn}$ and $\mathrm{Fe}$, very high status of each was prevailed as it was in previous status. There was an observation of higher micronutrient content in surface soils than the sub-surface soil in the present study. The reason could be attributed to addition of fertilizers and manures to surface soil during farming practices. In addition to that, other probable reasons for higher micronutrient content in surface soil could be due to the accumulation of biomass in the surface layer leading to higher organic matter and increased clay content in the surface soils. Similar observation was found by different authors (Vijayakumar et al., 2011; Singh and Shukla, 1985; Bassirani et al., 2011). Typical profile distribution of soil micronutrient is likely a result of higher decomposition of organic matter and crop residues that contribute to nutrient especially micronutrient accumulation to the top layers of soil. Again, root distributions and rooting depth have some impact on micronutrient profiles as nutrients taken up by deep roots are transported into the top soil layers and redeposited there through different mechanisms like stem flow (Garcia et al., 2014; Jiang et al., 2009; Franzluebbers et al., 1996).

Studied micronutrients except B had significant positive relation with clay content in surface soil while in sub-surface soil, only $\mathrm{Cu}, \mathrm{Fe}$ and $\mathrm{Mn}$ had significant positive relation. This might be due to the availability of binding sites for different cations on the clay particles. Increased total content of $\mathrm{Zn}, \mathrm{Cu}, \mathrm{Fe}$ and $\mathrm{Mn}$ was observed with an increase in soil clay content Sharma et al. (2004). Significant positive relation between soil Zn and clay content was also reported by some other scientists (Sarker et al., 2018; Mustapha and Fagam, 
2007). Soil available B was negatively correlated with clay content where the relation was non-significant. A good number of researchers found negative significant correlation between soil B and clay content. Worku et al. (2016) also found negative significant correlation between soil B and clay content $\left(r=-0.46^{* *}\right.$ ) which has conformity with Sharma et al. (2003) and Kumar and Babel (2010). Worku et al. (2016) also found negatively association $(\mathrm{r}=-0.16)$ between $\mathrm{Cu}$ and $\mathrm{pH}$ values. Other than $\mathrm{B}$, the micronutrients under study negatively correlated with soil $\mathrm{pH}$ in both surface and sub-surface soils which has conformity with some other researchers (Mustapha and Fagam, 2007; Mahashabde and Patel, 2012; Njukeng et al., 2013; Yadav, 2011). Available $\mathrm{Cu}, \mathrm{Fe}$ and $\mathrm{Mn}$ had strong association with soil organic matter content in surface soil.

In sub-surface soil only $\mathrm{Cu}$ and $\mathrm{Fe}$ had highly significant positive association with organic matter while positive but non-significant relation existed between $\mathrm{Mn}$ and organic matter content. The result of this study is in agreement with those reported by different authors (Goldberg et al., 2002; Wesley, 2004; Jacob and Joseph, 2008; Elbordiny et al., 2008; Vijayakumar et al., 2011; Mahashabde and Patel, 2012; Nath, 2013; Worku et al., 2016).

\section{Conclusion}

The depleting tendency of zinc (Zn) and boron (B) as revealed from the study is an awareness message for the agricultural research personnel as well as policy makers. The key findings of this study related to interactions and interrelationships among different soil parameters and nutrient elements will be helpful in planning soil management practices that will ensure the efficient use of soil resources in a sustainable manner.

\section{References}

Akhter, S., Ali, M.I., Jahiruddin, M., Ahmed, S., Rahman, L., 1990. A study of phosphorus-zinc interaction in rice. Bangladesh Journal of Crop Science 1(2): 99-109.

Alam, M.S., Islam, N., Jahiruddin, M., 2000. Effects of zinc and boron application on the performances of local and hybrid maize. Bangladesh Journal of Soil Science 26: 95-101.

Ali, M.I., 1991. Sustainable land management in Bangladesh-A strategic overview. In: Proceedings of International Symposium on Evaluation for Sustainable Land Management in the Developing World, Chiang Rai, Thailand, No. 12, pp.123-125.

BARC (Bangladesh Agricultural Research Council), 2012. Fertilizer Recommendation Guide, Farmgate, Dhaka, Bangladesh.

Bassirani, N., Abolhassani, M., Galavi, M., 2011. Distribution of available micronutrients as related to the soil characteristics of Hissar; Haryana (India). African Journal of Agricultural Research 6(18): 4239-4242.

BBS (Bangladesh Bureau of Statistics), 2017. Yearbook of Agricultural Statistics. Statistics and Informatics Division, Ministry of Planning, Government of the People's Republic of Bangladesh, p. 49.

BBS (Bangladesh Bureau of Statistics), 2018. 45 years Agriculture Statistics of Major Crops (Aus, Amon, Boro, Jute, Potato \& Wheat). Statistics and Informatics Division, Ministry of Planning, Government of the People's Republic of Bangladesh, pp. 33-98.

Bhuiya, Z.H., Idris, M., Jahiruddin, M., 1981. Response of IR8 to zinc fertilizer. International Rice Research Newsletter 6(6): 11.

Bhuiyan, M.A.H., Khanam, D., Khatun, M.R., Hassan, M.S., 1998. Effects of molybdenum, boron and Rhizobium on nodulation, growth and yield of chickpea. Bulletin Institute of Tropical Agriculture Kyushu University 21: 1-7.

Bray, R.H., Kurtz, L.T., 1945. Determination of total organic and available forms of phosphorus. Soil Science 59(1): 45-49.

Bremner, J.M., Mulvaney, C.S., 1982. Nitrogen total. In: Methods of soil analysis. Part 2 Chemical and microbiological properties. 2nd edition. Page, A.L., Miller, R.H., Keeney, D.R. (Eds.). American Society of Agronomy Inc., Madison, Wisconsin, USA. pp. 595-624.

Elbordiny, M.M., El-Dewiny, Y.C., 2008. Effect of some salt affected soil properties on micronutrients availability. Journal of Applied Sciences Research 4(11): 1569-1573.

Ferdoush, J.N.,Jahiruddin, M., Islam, M.R., 2003. Response of wheat to micronutrient in Old Brahmaputra Floodplain soil. Bangladesh Journal of Seed Science and Technology 7(1\&2): 35-38.

Fox, R.L., Olson, R.A., Rhoades, H.F., 1964. Evaluating the sulfur status of soils by plant and soil tests. Soil Science Society of America Journal 28(2): 243-246.

Franzluebbers, A.J., Hons, F.M., 1996. Soil-profile distribution of primary and secondary plant-available nutrients under conventional and no tillage. Soil and Tillage Research 39(3-4): 229-239.

García-Marco, S., Gómez-Rey, M.X., González-Prieto, S.Z., 2014. Availability and uptake of trace elements in a forage rotation under conservation and plough tillage. Soil and Tillage Research 137: 33-42.

Gee, G.W., Bauder, J.W., 1986. Particle size analysis. In: Methods of Soil Analysis, Part 1. Klute, A. (Ed.). American Society of Agronomy Inc. (ASA)-Soil Science Society of America Inc., (SSSA), Madison, Wisconsin, USA. pp. 383-411.

Goldberg, S., Shouse,P.J., Lesch, S.M., Grieve,C.M., Poss, J.A., Forster, H.S., Suarez, D.L., 2002. Soil boron extractions as indicators of boron content of field grown crops. Soil Science 167(11): 720-728.

Gomez, K.A., Gomez, A.A., 1984. Statistical procedures for agricultural research. John Wiley \& Sons. New York. USA. 
294p.

Huq, S., Rahman, A.A., Conway, G.R., 1990. Environmental aspect of agricultural development in Bangladesh. The University Press Limited, Dhaka, Bangladesh. pp. 3-7.

Islam, M.R., Riasat, T.M., Jahiruddin, M., 1997. Direct and residual effects of S, Zn and B on yield and nutrient uptake in a rice-mustard cropping system. Journal of Indian Society of Soil Science 45: 126-129.

Islam, M.S., 1984. Annual Report on zinc and sulphur deficiency problem in Bangladesh soils. FAO-BARC Coordinated Programme.

Islam, M.S., 2008. Soil fertility history, present status and future scenario in Bangladesh, Bangladesh Journal of Agriculture and Environment 4: 129-151.

Islam, S., 1990. The decline of soil quality. In: Environmental Aspect of Agricultural Development in Bangladesh. Huq, S., Rahman, A.A., Conway, G.R. (Eds.). The University Press Limited, Dhaka, Bangladesh. pp.3-7.

Jacob, C., Joseph, PV., 2008. Study of heavy metal levels in the soils of Pala Municipality area, Kerala. Pollution Research 27(2): 279-283.

Jahiruddin, M., Bhuiya, Z.H., Hoque, M.S., Rahman, L., 1981. Effect of rates and methods of zinc application on rice. Madras Agricultural Journal 68(4): 211-216.

Jahiruddin, M., Satter, M.A., 2010. Agricultural Research Priority: Vision 2030 and beyond. Bangladesh Agricultural Research Council, Farmgate, Dhaka, Bangladesh.

Jiang, Y., Zhang, G., Zhou, D., Qin, Y., Liang, W.J., 2009. Profile distribution of micronutrients in an aquic brown soil as affected by land use. Plant, Soil and Environment 155(11): 468-476.

Jones, L.H.P., Cowling, D.W., Lockyer, D.R., 1972. Plant-available and extractable sulphur in some soils of England and Wales. Soil Science 114(2): 104-114.

Keren, R. 1996. Boron. In: Methods of Soil Analysis, Part 3 - Chemical Methods. Sparks, D.L., Page, A.L., Helmke, P.A., Loeppert, R.H., Soltanpour, P.N., Tabatabai, M.A., Johnston, C.T., Sumner, M.E. (Eds.). American Society of Agronomy Inc., Madison, Wisconsin, USA. pp. 603-626.

Khanam, R., Arefin, M.S., Haque, M.A., Islam, M.R., Jahiruddin, M., 2000. Effects of magnesium, boron, and molybdenum on the growth, yield and protein content of chickpea and lentil. Progressive Agriculture 11(1\&2): 77-80.

Knudsen, D., Peterson, G.A., Pratt, P.F., 1982. Lithium, Sodium, and Potassium. In: Methods of soil analysis. Part 2 Chemical and microbiological properties. 2nd edition. Page, A.L., Miller, R.H., Keeney, D.R. (Eds.). American Society of Agronomy Inc., Madison, Wisconsin, USA. pp. 225-246.

Kumar, M., Babel, A.L., 2011. Available micronutrient status and their relationship with soil properties of Jhunjhunu Tehsil, District Jhunjhunu, Rajasthan, Indian Journal of Agricultural Sciences 3(2): 97-106.

Lal, R., Stewart, B.A., 1992. Needs for land restoration. In: Soil restoration. Lal, R., Stewart, B.A. (Eds.). Advances in Soil Science Vol. 17. pp.1-10.

Lindsay, W.L., Norvell, W.A., 1978. Development of a DTPA Test for zinc, iron, manganese and copper. Soil Science Society America Journal 42(3): 421-428.

Mahashabde, J.P., Patel, S., 2012. DTPA-extractable micronutrients and fertility status of soil in Shirpur Tahasil region. International Journal of ChemTech Research 4(4): 1681-1685.

McLean, E.O., 1982. Soil pH and Lime Requirement. In: Methods of soil analysis. Part 2 Chemical and microbiological properties. 2nd edition. Page, A.L., Miller, R.H., Keeney, D.R., (Eds.).American Society of Agronomy Inc., Madison, WI, USA. pp. 199-224.

Mustapha, S., Fagam, A.S., 2007. Influence of parent material on the contents and distribution of B and $\mathrm{Zn}$ in upland soils of Bauchi State, Nigeria. International Journal of Environmental Science and Technology 4(3): 359-362.

Nath, T.N., 2013. Determination of micronutrients concentration in tea cultivated soil in dibrugarh and sivasagar districts of Assam, India. International Journal on Innovative Research \& Development 2(4): 284-298.

Nelson, D.W., Sommers, L.E., 1996. Total Carbon, Organic Carbon, and Organic Matter. In: Methods of Soil Analysis, Part 3, Chemical Methods. Sparks, D.L., Page, A.L., Helmke, P.A., Loeppert, R.H., Soltanpour, P.N., Tabatabai, M.A., Johnston, C.T., Sumner, M.E. (Eds.). American Society of Agronomy Inc., Madison, Wisconsin, USA. pp. 961-1010.

Njukeng, J.N., Ehabe, E.E., Nkeng, G.E., Kratz, S., Schick, J., Schnug, E., 2013. Investigations on the nutritional status of Hevea brasiliensis plantations in the humid forest zone of Cameroon Part 1: Micronutrient status and distribution in soils. Journal of Cultivated Plants 65(10): 369-375.

Olsen, S.R., Sommers, L.E., 1982. Phosphorus. In: Methods of soil analysis. Part 2 Chemical and microbiological properties. 2nd edition. Page, A.L., Miller, R.H., Keeney, D.R., (Eds.). American Society of Agronomy Inc., Madison, WI, USA. pp. 403-430.

Piper, C.S., 1950. Soil and Plant Analysis. Adelaide University Hassel press. Australia.

Saheed, S.M., 1991. Land degradation and land stability constraints to crop production. In: Paper for the National Workshop on Risk Management in Bangladesh Agriculture, Bangladesh Agricultural Research Council, Farmgate, Dhaka, Bangladesh.

Saheed, S.M., 1994. The Collection and Analysis of Land Degradation Data, Country Report: Bangladesh, RAPA Publication: 1994/3, FAO Regional Office, Bangkok, pp. 69-87.

Sarker, M.M.H., Jahiruddin, M., Moslehuddin, A.Z.M., Islam, M.R., 2018. Available status and changing trend of micronutrients in floodplain soils of Bangladesh. SAARC Journal Agriculture 16(1): 35-48.

Saunders, D.A., 1990. Report of an On-Farm Survey: Dinajpur: Farmer Practices and Problems and Their Implications, Monograph No. 6, Wheat Research Centre, Bangladesh Agricultural Research Institute, Dinajpur. 
Saunders, D.A., 1991. Report of an On-Farm Survey: lessore and Kustia: Farmer Practices and Perceptions, Monograph No.8, Wheat Research Centre, Bangladesh Agricultural Research Institute, Dinajpur.

Sharma, B.D., Arora, H., Kumar, R., Nayyar, V.K., 2004. Relationships between soil characteristics and total and DTPAextractable micronutrients in Inceptisols of Punjab. Communications in Soil Science and Plant Analysis 35(5-6): 799-818.

Sharma, R.P., Megh, S., Sharma, J.P., 2003. Correlation studies on DTPA extractable micronutrients vis-à-vis soil properties in some soils of Nagaur district in semi-arid region of Rajasthan. Journal of the Indian Society of Soil Science 51: 522-527.

Siddique, M.N.E.A., Halim, M.A., Kamaruzzaman, M., Karim, D., Sultana, J., 2014. Comparative insights for investigation of soil fertility degradation in a piedmont area which cover the Anjamkhor Union of Baliadangi Upazila, Thakurgoan, Bangladesh. IOSR Journal of Environmental Science, Toxicology and Food Technology 8(4): 82-87.

Singh, K., Shukla, U.C., 1985. Response of wheat to zinc application in different soils of semi-arid region. Journal of Indian Society of Soil Science 33(4): 381-835.

SRDI (Soil Resource Development Institute), 2006. Land and Soil Resources Utilization Guide (in Bengali). Updated Upazila Nirdeshika series-24. Chandina upazila of Cumilla district, Bangladesh.

SRDI (Soil Resource Development Institute), 2010a. GIS map, Zinc Status of Bangladesh Soils. Farmgate, Dhaka, Bangladesh.

SRDI (Soil Resource Development Institute), 2010b. GIS map, Boron Status of Bangladesh Soils. Farmgate, Dhaka, Bangladesh.

SRDI (Soil Resource Development Institute). 1999. Land and Soil Resources Utilization Guide (in Bengali). Thana Nirdeshika series-279. Adorsho Sadar upazila of Cumilla district, Bangladesh.

SRDI (Soil Resource Development Institute). 2000. Land and Soil Resources Utilization Guide (in Bengali). Thana Nirdeshika series-333. Burichong upazila of Cumilla district, Bangladesh.

Tabatabai, M.A., 1996. Sulphur. In: Methods of Soil Analysis, Part 3 - Chemical Methods. Sparks, D.L., Page, A.L., Helmke, P.A., Loeppert, R.H., Soltanpour, P.N., Tabatabai, M.A., Johnston, C.T., Sumner, M.E. (Eds.). American Society of Agronomy Inc., Madison, Wisconsin, USA. pp. 921-960.

Vijayakumar, R., Arokiaraj, A., Martin, P.P., 2011. Micronutrients and their relationship with soil properties of natural disaster proned coastal soils. Research Journal of Chemical Sciences 1(1): 8-12.

Wesley, S.G., 2004. Bioaccumulation of heavy metals by the intertidal molluscs of Kanyakumari waters. Indian Pollution Research 23(10): 37-40.

Worku, A., Bedadi, B., Mohammed, M., 2016. Assessment on the status of some micronutrients of salt affected soils in Amibara area, central rift valley of Ethiopia. Academia Journal of Agricultural Research 4(8): 534-542.

Yadav, B.K., 2011. Micronutrient status of soils under legume crops in arid region of western Rajasthan, India. Academic Journal of Plant Sciences 4(3): 94-97. 